\title{
Estimating the Students' Skill in Reciting and Writing Alqur'an at Faculty of Tarbiyah and Teacher Training IAIN Sultan Amai Gorontalo
}

\author{
Lian G. Otaya \\ IAIN Sultan Amai Gorontalo \\ lianotaya@iaingorontalo.ac.id \\ Herson Anwar \\ IAIN Sultan Amai Gorontalo \\ herson.anwar@iaingorontalo.ac.id \\ Rahmin Talib Husain \\ IAIN Sultan Amai Gorontalo \\ rahminhusain@iaingorontalo.ac.id
}

\begin{abstract}
The purpose of this study was to estimate the instrument of reading and writing capability of the Qur'an in the practicum program students of the Faculty of Tarbiyah and Teacher Training IAIN Sultan Amai Gorontalo. This type of research is quantitative with an analysis approach to the generalization theory variance through the G-Study concept with a multifacet design $\mathrm{p} \times \mathrm{r} \times \mathrm{I}$ three facet variations. The results of the study prove the instrument of reading and reading ability of the Koran was tested, namely the estimated coefficient of reliability of the combined scores of the reading and writing assessment of the Koran from 20 students who were rated by 4 rater of 10 items which were judged by the magnitude of generalizability coefficient value of 0.82749 . The magnitude of this value indicates that the true score of the assessment results is quite high compared to the minimum reliability criteria, which is 0.70 fulfilling the reliable criteria.
\end{abstract}

Keywords: assessment; writing and reciting Alqur'an; generalizability study;

\begin{abstract}
Abstrak
Tujuan penelitian ini untuk mengestimasi instrument kemampuan baca tulis alqur'an pada program praktikum baca tulis Alqur'an mahasiswa Fakultas Ilmu Tarbiyah dan Keguruan IAIN Sultan Amai Gorontalo. Jenis penelitian ini menggunakan kuantitatif dengan pendekatan analisis varians teori generalisibilitas melalui konsep G-Study dengan desain multifacet p x r x I tiga variasi facet. Hasil penelitian membuktikan instrumen penilaian kemampuan baca tulis al-Qur'an teruji, yakni estimasi koefisien reliabilitas skor gabungan penilaian kemampuan baca tulis Alqur'an dari 20 mahasiswa yang dinilai oleh 4 rater terhadap 10 item yang dinilai diperoleh besarnya nilai koefisien generalizabilitas sebesar 0,82749. Besaran nilai tersebut menunjukkan bahwa true score hasil penilaian cukup tinggi dibandingkan kriteria reliabilitas minimal yaitu 0,70 memenuhi kriteria reliabel.
\end{abstract}

Kata Kunci: $\quad$ Penilaian; Baca Tulis Alqur'an; Studi Generalizabilitas; 


\section{Introduction}

The University management learning process is very responsible in reviewing and evaluating the activities of study program especially in implementing learning activities (SNDikti, Article 39 Section 3). It is in line with Constitution No. 20 Year 2003 about national education system, article 57 states that (1) evaluation is conducted in order to nationally control the quality of education as a form of accountability from the education stakeholders to other related parties. University as a the producer of educated human resources should measure its graduates, whether the graduates produced in every circumstances have 'ability' which is level with 'ability' (learning achievement). As formulated in Constitution No.12 Year 2012 Article 35 Section 2 that the High level education curriculum is developed by every university by referring to the High Level National Education Standard for each study program which covers the development of intelligence, attitude and behaviour, and skill.

The learning achievement is measured through assessment activity. Assessment will be beneficial to see the quality of education as a whole and the assessment will also provide essential information to improve the education process because the assessment is able to describe comprehensive learning outcome1. Assessment is the process of determining the value of a particular object based on certain criteria2. To get information about the results of the learning process, an assessment is totally needed3. Therefore, if the main aim is to improve the quality of learning, it is necessary to improve the quality of the assessment, because

1 Ofianto and Suhartono, "An Assessment Model Of Historical Thinking Skills By Means Of The Rasch Model", Research and Evaluation in Education Journal, Vol. 1, No. 1 (2015), 73-83. Retrieved from: http://journal.uny.ac.id/index.php/reid.

2 Lian G. Otaya, "Urgensi Sikap Mahasiswa Menilai Kemampuan Diri Dalam Belajar Melalui Asesmen Diri (Self Assessment)", Tadbir Jurnal Manajemen Pendidikan Islam, Vol. 3, No.1 (2015), 58-67.

3 Alita Arifiana Anisa, "Students' Literature Achievement: Predictors Investigation Research", Research and Evaluation in Education, Vol. 3, No. 2 (2017), 144-51. Retrieved from: http://journal.uny.ac.id/index.php/reid. 
the assessment includes all the methods used to collect data about the individual and focus on the individual, so that the decision is also on the individual. Therefore, the assessment plays a very strategic role in measuring the learning outcome relevant to the vision and mission of the university, one of which is the assessment of the Al-Qur'an literary practice at the Faculty of Tarbiyah and Teacher Training IAIN (FITK) Sultan Amai Gorontalo.

The Al-Qur'an reciting and writing practicum program at FITK Sultan Amai Gorontalo IAIN was conducted as an effort to improve the ability of students in Al-Qur'an recital and writing. It is in line with the paradigm of the unity of science brought by the vision of Sultan Amai Gorontalo IAIN making the practice of reciting and writing Al-Qur'an has a distinctiveness not only to provide the knowledge and skill of reciting and writing the Qur'an, but also to instil a sense of faith and devotion to the God Almighty, as well as developing a personality into a human with moral character and being able to internalize it in daily life. This effort also departs from the current problems of Al-Qur'an learning in Indonesia, including Giftia (2014) stating that the reality of Muslim in Indonesia today is very concerning in terms of the ability to recite and write Arabic4. Tamrin (2016) states that the AlQuran literacy rate in Indonesia is relatively high according to the 2013 Central Bureau of Statistics (BPS) data that there are around $54 \%$ of the total population of Muslims in Indonesia who cannot recite Al-Quran5.

Various studies related to the literacy ability of the $\mathrm{Al}$ Quran among students, especially in the Faculty of Tarbiyah and Teacher Training in IAIN in Indonesia showed that their

4 Gina Giftia, "Peningkatan Kemampuan Baca Tulis Huruf Al-Qur'an Melalui Metode Tamam Pada Mahasiswa Fakultas Sains Dan Teknologi UIN Sunan Gunung Djati Bandung", Jurnal Istek, Vol. VIII, No.1 (2014), 14258. Retrieved from: http://journal.uinsgd.ac.id/index.php/istek/article/view/ 210/226.

5 Tamrin, "Pola Pembinaan Tahsin Alquran Di Kalangan Mahasiswa (Analisis Pola Pembinaan Pada Himpunan Qari Qariah Mahasiswa Sulawesi Tengah (HIQMAH) ", Rausyan Fikr, Vol. 12, No.2 (2016), 315-50. 
abilities were still very low among others. Samad (2012) found that the majority of the Al-Qur'an literacy skills at the IAIN Sultan Amai Gorontalo were very low. It is influenced by the low interest in learning to recite and write Al-Qur'an by students and also by the heterogeneous characteristics of incoming students including those from high school / vocational school even though they have received the introduction of Al-Qur'an reciting and writing since elementary school (SD) or junior high school (SMP)6. Suviana (2016) found that there was still a lack of ability to memorize short verses in juz 30 of Al-Qur'an among students at Faculty of Tarbiyah and Teacher Training (FTIK), some of them were only able to memorize without paying attention to the correct reciting rules and ultimately affect the quality of output expected.7. Besides that, many parents are more anxious if their children are poor on Mathematics, English or other sciences than demanding them to have better knowledge about Al-Qur'an8. It is in line with the finding of Hasri and Rahmah (2016) that the ability of students to understand mathematics is inversely proportional to the ability to understand Al-Qur'an recital, students' mathematical reasoning abilities are sometimes not equivalent to the literacy skills they have, so the dichotomy often occurs between students who can recite and write Al-Qur'an with students who have mathematical abilities.9

6 Musdelifa Abu Samad, "Sistem Pembelajaran Bahasa Arab Di IAIN Sultan Amai Gorontalo" Program Pascasarjana Universitas Islam Negeri (UIN) Alauddin Makassar, 2012.

7 Vivin Andria Suviana, "Implementasi Praktikum Baca Tulis AlQur'an (BTQ) Dalam Mengembangkan Kemampuan Menghafal Al-Qur'an Mahasiswa Jurusan Tadris Matematika (TMT) FTIK IAIN Tulungagung Tahun 2015", Institut Agama Islam Negeri Tulungagung, 2016.

8 Abul A'la al Maududi, Endin Mujahidin, and Didin Hafidhuddin, "Metode Tahfizh Al-Qur'an Bagi Pelajar Dan Mahasiswa", Ta'dibuna: Jurnal Pendidikan Islam, Vol. 3.1 (2014), 1-15.

9 Hasri dan Nur Rahmah, "Kemampuan Baca Tulis Al - Quran Dan Korelasinya Terhadap Kemampuan Matematika Mahasiswa Prodi Tadris Matematika IAIN Palopo", Al-Khwarizmi: Jurnal Pendidikan Matematika Dan Ilmu Pengetahuan Alam, Vol. 4, No.2 (2016), 163-72. 
Another study conducted by Jumaeda (2017) found that the low ability to recite and write Al-Qur'an for students who are entering IAIN has implications for their low ability to learn and master Islamic sciences and this phenomenon has basically been detected from the beginning of student admission, where some large prospective students have difficulty in answering Arabic tests.10 Rohimin (2017) found reality in the field that there were students until the end of the study before being able to recite Al-Qur'an when Practicing Field Experience (PPL), Proposal Seminars, and Munaqasah.11 Moreover, IAIN is an Islamic education institution that is capable in supporting its students and graduates to have better understanding about Al-Qur'an.

The ability to recite and write Al-Qur'an is the sequentially ability, by reciting and writing. Where a person has a skill in reciting well and correctly as the rules of recitation, writing by copying the series of the appropriate hijaiyyah letters, neat and beautiful relating to the verses of the Al-Qur'an12. Mssraty \& Faryadi (2012) states tajwid is a word in Arabic which means the correct pronunciation of the verses of Al-Qur'an and must be considered in reciting the AlQur'an for the truth of its meaning in accordance with the verses of Al-Qur'an13. Besides that, reciting Al-Qur'an must be fluent as appropriate with the makhraj letters, so that the meaning contained in the sentences are not deviated, because

10 St. Jumaeda, "Ma'had Al -Jamiah Di Institut Agama Islam Negeri Ambon", Jurnal Al-Iltizam, Vol. 2, No.1 (2017), 1-11.

${ }_{11}$ Chairur Rohimin, "Pelaksanaan Program Baca Tulis Al-Qur'an Di P3KMI IAIN Surakarta Tahun Akademik 2016/2017", Institut Agama Islam Negeri Surakarta untuk, 2017.

12 Nur Hafidhotul Hasanah, "Efektifitas Pelaksanaan Program Ekstrakurikuler Baca Tulis Al-Qur'an Bagi Siswa Kelas VII MTsN Sumberagung Jetis Bantul", Jurnal Pendidikan Agama Islam, Vol. X, No.1 (2013), 59-85.

13 Tariq Mssraty and Qais Faryadi, "Teaching the Qur' Anic Recitation with Harakatt: A Multimedia-Based Interactive Learning Method", International Journal of Scientific \& Engineering Research, Vol. 3, No.8 (2012), 1-4. 
one letter is wrong its meaning will be different14. Therefore, Al-Qur'an literacy ability is one of the competencies required for every student in the department / study program at FITK IAIN Sultan Amai Gorontalo in taking the comprehensive and Munaqasah examinations.

To support the achievement of these competencies, an important and urgent reciting and writing practicum is conducted, so that the early semester students are required to attend this program and this practicum. It is included in the FITK curriculum with zero (0) semester credit units (SKS) using the Al-Quran Writing Reciting Method (MBTA) through the guidance of lecturers to be skilled in reciting and writing correctly. This activity was preceded by a placement test which aimed to identify students' initial abilities and groupings, such as groups who were fluent in reciting and fluent in writing Al-Qur'an, groups that recite fluently but the tajwid or makhrijul letters were not clear, groups that were not fluent and illiterate or not have the ability to recite and write Al-Qur'an. After participating in the practicum, each student takes an exam to find out the results of his examination which is for students who are declared to pass will get a certificate that indicates the ability in reciting and writing Al-Quran, while students who are declared not graduated are given the opportunity to study again. But the reality in the field shows otherwise, even though students have taken practicums and declared graduated, most students are tested for their ability to recite and write Al-Qur'an during seminar proposal, comprehensive examination and Munaqosah has not been able to recite and write Al-Qur'an properly and correctly in accordance with the legal rules of reciting and recitation.

Noticing the problem above, it is necessary to design an Al-Quran literacy practice assessment for students of the Faculty of Tarbiyah and Teacher Training who are able to

14 Muhammad Rizki, "Pembinaan Kemampuan Membaca Al-Qur'an Mahasiswa Prodi Pendidikan Agama Islam Melalui Program Ma'had AlJamiah UIN Ar-Raniry", Universitas Islam Negeri Ar-Raniry, 2016. 
reveal the achievements of the students' Al-Quran literacy skills. This is very important for gathering evidence about AlQur'an literacy achievement for each student based on the criteria assessed and accurate data. In obtaining the data, it requires a good measuring instrument and has the same perception from the lecturer as the assessor (rater) and students as the subject being assessed (Pearson) related to the achievement of the Al-Quran literacy skills assessed. Without a valid and reliable assessment, it is assumed that there is a systematic error in evaluating students' Al-Quran literacy skill. All irrelevant things that influence the assessment are a source of errors in assessing Al-Quran's literacy skills both from the lecturer as the appraiser, the assessment instrument used as a measure and the characteristics of students becomes the subject in an assessment.

For this purpose, the design of assessment for reciting and writing of the Al-Qur'an students is needed by using the inter-rater reliability analysis method, requiring the rater to directly assess the Al-Qur'an literacy skill of students with the same assessment criteria from three indicators: (1) fluency /fluent); (2) the truth of reading (tajwid); (3) the fluency in writing of Al-Quran according to the rules. This assessment design needs to estimate inter-rater reliability using generalizability theory which is basically an analysis of variance that is estimating reliability as a function of various components, such as person, item, rater which is the basis in determining inter-rater reliability to explain more detailed measurement errors including sources of errors in the assessment of the Al-Qur'an literacy skill of the students.

The success of students in practice is determined by lecturers who are tasked with providing constructive direction in terms of reciting and writing Al-Quran in every aspect such as makhroj, tajwid, and the correct rules of writing Al-Quran. The most important thing that must be considered by students is to follow the instruction and direction from the lecturer. But there is a tendency that the assessment of each lecturer varies depending on the willing, 
perception, background of education and experience. This problem raises the premise that all this time the assessment of Al-Qur'an literacy skill is appropriate with what is desired, known, has been studied and experienced by each lecturer. Therefore, this research is very important and urgent in overcoming the existing problems related to the assessment of students' Al-Qur'an literacy practice which involves three measurement conditions, they are: person, item, rater. This study aims to analyse the assessment instrument which is developed as feasible or not suitable to be used in assessing the ability of students in Al-Qur'an literacy practicum activities in the Faculty of Tarbiyah and Teacher Training of IAIN Sultan Amai Gorontalo.

\section{Method}

This type of research is quantitative with an analysis approach to the generalization theory variance through the GStudy concept with a multifacet design $\mathrm{p} \times \mathrm{r} \times \mathrm{I}$ three facet variations namely, participant / person (p), rater (r), and component / item (i). The research data consist of primary data and secondary data. Primary data were obtained from observation in the form of observation score on students' AlQuran literacy skill which is in accordance with the observed aspects of the indicators by the assessor / rater or lecturer. Secondary data were obtained from document studies that was the results of Al-Qur'an writings from each student. The subjects in this study were students in the first semester of the academic year 2017/2018 in Islamic Education Management Study Program, FITK IAIN Sultan Amai Gorontalo with total 20 students as a sample with a purposive sampling technique.

The data analysis technique is obtained by estimating reliability for the price of the reliability coefficient obtained from the comparison between the pure score variant and the variance of the observation score computed using a technique developed by Thorndike, then the coefficient value generated compared to the minimum reliability 
criteria allowed by Linn (1990) which is 0,7015. The estimated coefficients produced were analysed with the help of GENOVA 3.1 software program, "A Generalized Analysis of Variance System" developed by Crick and Brennan in 1983. This program has some advantages in estimating reliability as a function of various component such as person, items, or rater which becomes the basis for determining inter-rater reliability in more detail.

\section{Result}

The ability of students in Al-Qur'an literacy practice is a basic ability that must be possessed by every FITK student. With the good literacy skills of Al-Quran, it will help them in understanding the lecture material specifically related to religion subject such as Arabic Language course, Ulumul Hadith, Ulumul Qur'an, Interpretation of Hadith, Tafsir Tarbawi, Islamic Education and others. If students have been able to recite and write Al-Quran, it will help in memorizing, understanding, copying, translating, and concluding the content of Al-Quran and being able to practice it in daily life. Through the design of assessment with multifaceted generalizability studies, it is more able to explain errors in measuring student ability assessment in Alqur'an literacy because in generalizing of theory, observation (for example the assessment of tested examination) are seen as samples of the universe (population) of admissible observation. The Universe describes condition, which is tested and observable, which produces equivalent results at several specific levels. A tested population score is set by the expected score of the observation exceeding all universe of admissible observation (observation that is acceptable).

Based on the results of the assessment of Alquran's literacy skill from 20 students assessed from three indicators, they are: (1) fluency in reading (makhroj /fluent); (2) the truth of reading (tajwid); (3) the fluency in writing Al-Qur'an according to the rules of writing and judged by 4 (four) assessors / lecturers or lecturers using the Genova program obtained outputs of mean square values that can be used to calculate the price of the seven components of variance as shown in the table 1 :

15 Robert L. Linn, "Measurement and evaluation in teaching", New York: Macmillan Publishing Company, (1990), 143. 
Table 1. The Value of Combined Mean Square Assessment of Students' Alqur'an Reciting and Writing Skill

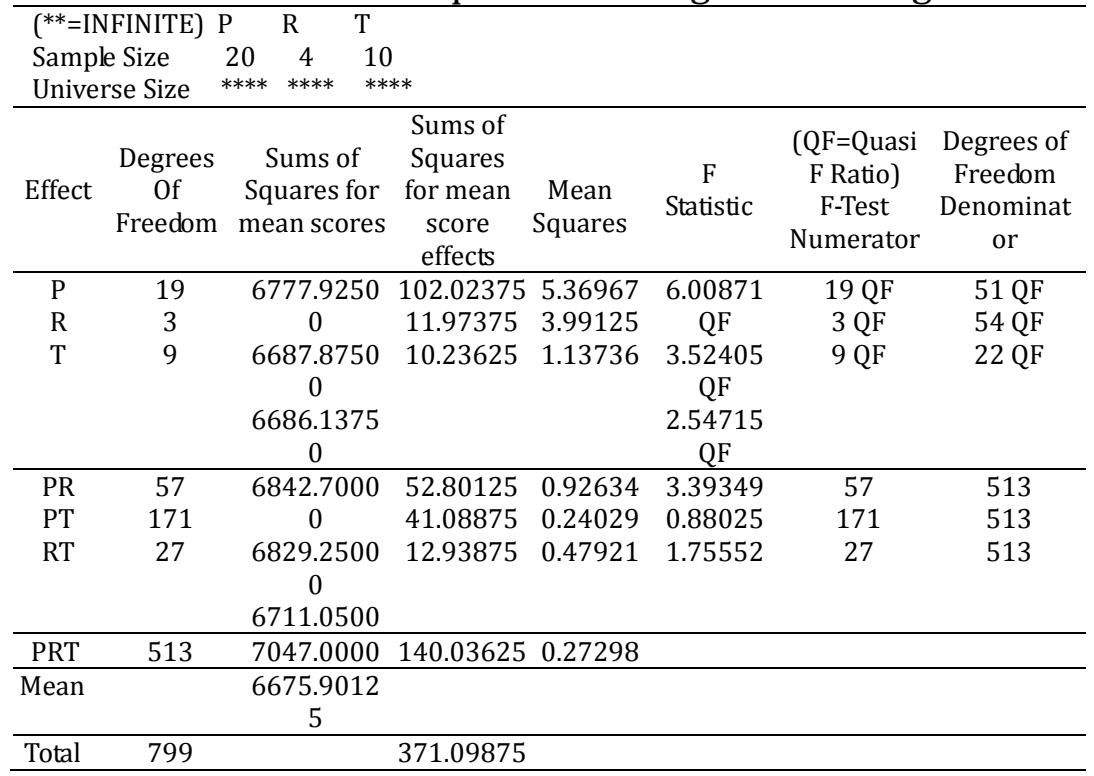

Based on the presentation of the analysis results in table 1 , information is obtained that there are seven sources of variance, those sources are: $\mathrm{P}, \mathrm{R}, \mathrm{T}, \mathrm{P} * \mathrm{R}, \mathrm{P}{ }^{*} \mathrm{~T}, \mathrm{P} * \mathrm{~T}, \mathrm{P} * \mathrm{R} * \mathrm{~T}$. Each source of variance has a free degree, number of squares and mean squares as presented in table 1 . As the result of data analysis, it is also estimated the variability in each effect (source of variation). The estimation of variability illustrates the magnitude of the error in each effect from the assessment of Al-Qur'an literacy skill which was assessed from 20 students and assessed by 4 rater students. The calculation of the seven components of the variance with the help of the Genova 3.1 program is presented in table 2 below:

Table 2. The Variance of Combined Score of Students' Alqur'an Reciting and Writing Skill Assessment Model 
Lian G. Otaya, at. all $\mid 85$

\begin{tabular}{cccccc}
\hline & & & & & Variance Components for mean \\
scores
\end{tabular}

Reliability estimation through ANOVA analysis is the ratio or comparison between pure score variance and observed score variance by entering the value of each combined score variance above into the reliability formula $\left(\mathrm{r}_{\mathrm{xx}^{\prime}}\right)$. From the results of the ratio calculation or the comparison between the pure score variance and the observed score variance, the same coefficient of joint score reliability as obtained from the Genova output is shown in table 3:

\begin{tabular}{|c|c|c|c|c|}
\hline & Variance & $\begin{array}{l}\text { Standard } \\
\text { Deviation }\end{array}$ & $\begin{array}{c}\text { Standard } \\
\text { Error of } \\
\text { Variance }\end{array}$ & Generalizability coefficient= \\
\hline Universe Score & 0.11108 & 0.33329 & 0.04165 & $0.82749(4.79667)$ \\
\hline $\begin{array}{l}\text { Expected observed } \\
\text { score }\end{array}$ & 0.13424 & 0.36639 & 0.04143 & Phi $=0.79976(3.99404)$ \\
\hline Lower Case Delta & 0.02316 & 0.15218 & 0.00433 & \\
\hline
\end{tabular}




\begin{tabular}{l}
\hline Upper Case Delta $\quad 0.027810 .16677 \quad 0.00522$ \\
\hline Mean \\
\hline Table 3. Reliability Coefficient of Combined Score Using Genova \\
Based on the comparison between the pure score \\
variance and the observed score above, it was found that the \\
reliability coefficient design of the combined score of Al- \\
Quran literacy skill assessment from 20 students was \\
assessed by 4 raters as follows.
\end{tabular}

\section{The Result of G Study}

The estimation of reliability coefficients in resulting $G$ study were analysed with the help of the GENOVA program. The reliability coefficient values were obtained from comparisons between pure score variant and computed score variant using a technique developed by Thorndike. Based on the results of the analysis of the students' AlQur'an reciting and writing skill assessed by 4 raters, the generalizability coefficient value is 0.82749 for 20 people with 10 items developed from 3 indicators: the fluency of reciting (makhroj / fluent), truth in reading (tajwid), and the fluency in writing Al-Qur'an according to the rules. The amount of the generalizability coefficient is quite adequate and shows that the true score on the results of the assessment of the students' Al-Qur'an literacy ability is quite high, because the value of $r_{x x^{\prime}}$ 'is more than 0.70 from the minimum reliability criteria permitted by Linn (1990), it can be concluded that the instrument used in the assessment of students' Al-Qur'an reciting and writing practice in the Faculty of Tarbiyah and Teacher Training are reliable, so that the assessment instrument is appropriate to be used to assess the students' Al-Qur'an literacy skill. The G Study result according to Shavelson (2015) offers a concept and framework for estimating various sources of variance scores16. An essential step in the G Study is to describe and partition the sources of error variance that may arise in a

16 Richard J. Shavelson, "Generalizability Theory", (New Bury Park California: Sage Publications, 2017) Retrieved from: https://doi.org/10.1002/9781118625392.wbecp352. 
measurement implementation, because this study provides a model and method that allows to parse some sources of 17 . Therefore, this analysis is able to describe and partition the sources of error variance that might appear in Al-Qur'an reciting and writing practice assessment.

\section{The Result of D Study}

D Study is a study of the generalizability theory in determining decisions related to the results of the generalizability coefficient in various variations of rater. The results of the generalizability coefficients that have been presented previously are the results of generalizability estimation if the measurement conditions are using 4 rater. However, in the study of generalizability estimation in various variations of rater was conducted, starting from the use of 1 rater, 2 raters, 3 raters and 4 raters. It is conducted to see the distribution of the generalizability coefficient of each condition. The results of D analysis through Genova 3.1 obtained generalizability coefficient for the use of 1 rater which was 0.76886 , for the use of 2 raters generalizability coefficient was 0.78746 , while for using 3 raters the generalizability coefficient was 0.80036 , and for 4 raters generalizability coefficient was 0.80984 .

Based on the analysis result, information is obtained that the more rater, the higher the generalizability coefficient of the Al-Quran literacy skill in the assessment instrument. However, the results show that the use of 3 raters has shown a sufficient coefficient for the assessment of students' Al-Quran literacy skill. The difference of coefficient between $\mathrm{G}$ coefficients which uses 3 raters with generalizability coefficient when using 4 raters is not too far away. Therefore, the result of $\mathrm{D}$ Study on practicum assessment design decided on 3 raters for the assessment of Al-Quran literacy skill which was tested on 20 students of Islamic Education Management Study Program at FITK IAIN

17 Brennan, Robert L, "Performance Assessments From the Perspective of Generalizability Theory", Applied Psychological Measurement, 24 (2000), 339-53. 
Sultan Amai Gorontalo. The selection for the use of 3 raters is based on the consideration of practicality, time spent, and the costs required to conduct the practicum activity.

Various research results indicate the importance of reliability estimation and generalizability studies in an assessment including Fan \& Sun (2013) stating that generalizability study (G-Study) provide a comprehensive and integrated framework for measuring reliability18. Briesch et. all (2014) that G-Study focuses on estimating the level of measurement variance caused by various sources of variance, or aspects (for example the opportunity, assessor, and item)19. Graham, et. al (2014) that the G-Study is able to estimate how many samples are needed to get an acceptable level of reliability20. Bahrudin dan Kumaidi (2014) state that if the proof of validity and estimation of reliability produces a coefficient value which is greater or at least equal to the coefficient criteria specified, then the assessment instrument can be stated to be valid and reliable, so it is feasible to be used21. Herwin and Sumantri (2015) stated that G-Study described and partitioned sources of error variance that might appear in a measurement implementation and one of the characteristics of G-Study which was the application of the analysis of variance data

18 Xitao Fan and Shaojing Sun, "Generalizability Theory as a Unifying Framework of Measurement Reliability in Adolescent Research", Journal of Early Adolescence, Vol. 34, No.1 (2014), 38-65. Retrieved from: https://doi.org/10.1177/0272431613482044.

19 Amy M Briesch and others, "Generalizability Theory: A Practical Guide to Study Design, Implementation, and Interpretation", Journal of School Psychology, Vol. 52, No.1 (2014), 13-35. Retrieved from: https://doi.org/10.1016/j.jsp.2013.11.008.

20 Steve Graham and others, "Assessing the Writing Achievement of Young Struggling Writers: Application of Generalizability Theory", Learning Disability Quarterly, 2015, 1-10. Retrieved from: https://doi.org/10.1177/0731948714555019.

21 Bahrudin dan Kumaidi, "Model Asesmen Musabaqah Tilawah AlQuran (MTQ) Cabang Tilawah", Jurnal Penelitian Dan Evaluasi Pendidikan, Vol. 18, No.2 (2014), 153-67. 
from the assessment result22. Han (2016) G-Study is able to describe several sources of error by estimating component variance related to the measurement aspect 23 .

Some advantages of generalizability theory compared to classical test theory for estimating instrument reliability include: (1) this theory is able to show a stimulant overall measurement error, (2) this theory estimation takes into account the effects of measurement errors due to interaction between components, (3) this theory estimate the coefficient of reliability by determining the ratio between actual person variances and observed variance person. Usually, two facets (measurement condition, such as grader and item) will be associated as $p$, $i$ and $h$ which represent the measurement object (often a person or participant, but not always). $P$ means person, $I$ means facet condition I, $h$ means facet $H$. The analysis of standard variance, effects in design can be identified as main effects and interaction effects, from this perspective $\mathrm{p}$ is the main effect for example the design of $p \times i \times h$, the main effect of $\mu p \sim, \mu i \sim, \mu h \sim$ and all other effects (except $\mu$ ) which is an interaction effect 24 .

Noticing to the importance of the design assessment of the Al-Qur'an reciting and writing practice of students at FITK IAIN Sultan Amai Gorontalo through the generalizability study above is a challenge and at the same time a huge opportunity for other researchers to conduct

22 Herwin dan Sumantri, "Studi Generalizabilitas Multifacet Pada Instrumen Penilaian Menulis Karangan Di Sekolah Dasar", in Prosiding Kongres Dan Konferensi Ilmiah Himpunan Evaluasi Pendidikan (HEPI) Tahun 2015, pp. 155-59.

${ }_{23}$ Chao Han, "Investigating Score Dependability in English / Chinese Interpreter Certification Performance Testing: A Generalizability Theory Approach Investigating Score Dependability in English / Chinese Interpreter Certification Performance Testing: A Generalizabi", Language Assessment Quarterly, Vol. 13, No. 2 (2016), 186-201. Retrieved from: https://doi.org/10.1080/15434303.2016.1211132.

24 L.N Izza, E. Susilaningsih, and Harjito, "Analisis Instrumen Performance Assessment Dengan Metode Generalizability Coefficient Pada Keterampilan Dasar Laboratorium", Chemistry in Education, Vol. 3, No.1 (2014), 30-36. Retrieved from: http://journal.unnes.ac.id/sju/index.php. 
further research on a broader scale, so that the problem of learning Al-Quran by students can be solved. Considering the learning in reciting and writing Al-Quran is a must for every Muslim. It is also in line with the agreement of the Ulama that the main goal of Al-Qur'an learning is to create a generation of huffaz who are able to maintain Al-Qur'an from every deviation25. Therefore, it is expected that the finding of this research will provide constructive input in assessing the Al-Qur'an literacy skill, especially for the quality of the reciting and writing aspects such as: fluency in reading (makhroj/fluent), the truth in reading (tajwid) and the fluency in writing of Al-Qur'an appropriate with the rules. From those who were initially unable or unable to recite and write Al-Qur'an, they were able to do it fluently, well and correctly because the design of this instrument based on the result of the analysis which was declared appropriately in assessing the literacy skills of each student based on indicators observed. This thing will certainly support the vision and mission conducted by the Faculty of Tarbiyah and Teacher Training in producing Islamic graduates, because of the public tendency that graduates from Islamic universities should have sufficient insight and ability in religious aspects and other general knowledge as well as the characteristic and selling value of graduates in the community.

\section{Conclusion}

The design of the assessment of students' Al-Qur'an literacy practice in the Faculty of Tarbiyah and Teacher Training based on instrument analysis using multifaceted generalizability study developed from 3 indicators, they are: fluency in reciting (makhroj / fluent), the truth in reading (tajwid), and fluency in writing Al-Qur'an which can be used to assess the ability of students in practice. It is shown from

25 Muhammad Hafiz Saleh and others, "Developing An Effective Quran Memorisation Technique Using Fuzzy Delphi Method", Al-Qanatir: International Journal of Islamic Studies, Vol. 7, No.1 (2017). Retrieved from: http://myjms.mohe.gov.my/index.php/alqanatir. 
the estimation of the reliability coefficient of the combined score assessment fulfilling the required reliable criteria, so that the assessment conducted by the lecturer will have the same perception. In conducting an assessment of the literacy skills, each student is assessed and the assessment conducted will be very effective for students who are able to recite AlQur'an according to makhroj / fluent and tajwid and also able to write it according to the rules of writing. The students who fulfil the criteria above have a great opportunity to graduate in this practicum activity. While for students who have not been able to fulfil the requirement, have a small opportunity to graduate and of course it becomes an input for lecturers to provide opportunities for students to learn again based on the difficulties they face. The great expectation of this finding is to improve the Al-Quran literacy skill of the students at Faculty Tarbiyah and Teacher becoming better and excellent.

\section{References}

Al Maududi, Abul A'la, Endin Mujahidin, and Didin Hafidhuddin, "Metode Tahfizh Al-Qur'an Bagi Pelajar Dan Mahasiswa", Ta'dibuna: Jurnal Pendidikan Islam, Vol. 3.1 (2014), 1-15.

Anisa, Alita Arifiana, "Students' Literature Achievement: Predictors Investigation Research", Research and Evaluation in Education, Vol. 3, No. 2 (2017), 144-51. Retrieved from: http://journal.uny.ac.id/index.php/reid.

Bahrudin, dan Kumaidi, "Model Asesmen Musabaqah Tilawah Al-Quran (MTQ) Cabang Tilawah", Jurnal Penelitian Dan Evaluasi Pendidikan, Vol. 18, No.2 (2014), 153-67.

Brennan, Robert L, "Performance Assessments From the Perspective of Generalizability Theory", Applied Psychological Measurement, 24 (2000), 339-53.

Briesch, Amy M, Hariharan Swaminathan, Megan Welsh, and Sandra M Chafouleas, "Generalizability Theory: A Practical Guide to Study Design, Implementation, and Interpretation", Journal of School Psychology, Vol. 52, 
92 | Lian G. Otaya, at. all

No.1 (2014), 13-35. Retrieved from: https://doi.org/10.1016/ j.jsp.2013.11.008.

Fan, Xitao, and Shaojing Sun, "Generalizability Theory as a Unifying Framework of Measurement Reliability in Adolescent Research", Journal of Early Adolescence, Vol. 34, No.1 (2014), 38-65. Retrieved from: https://doi.org/10.1177/0272431613482044.

Giftia, Gina, "Peningkatan Kemampuan Baca Tulis Huruf AlQur'an Melalui Metode Tamam Pada Mahasiswa Fakultas Sains Dan Teknologi UIN Sunan Gunung Djati Bandung", Jurnal Istek, Vol. VIII, No.1 (2014), 142-58. Retrieved from:

http://journal.uinsgd.ac.id/index.php/istek/article /view/210/226.

Graham, Steve, Michael Hebert, Michael Paige Sandbank, and Karen R Harris, "Assessing the Writing Achievement of Young Struggling Writers: Application of Generalizability Theory", Learning Disability Quarterly, 2015, 1-10. Retrieved from: https://doi.org/10.1177/ 0731948714555019.

Han, Chao, "Investigating Score Dependability in English / Chinese Interpreter Certification Performance Testing: A Generalizability Theory Approach Investigating Score Dependability in English / Chinese Interpreter Certification Performance Testing: A Generalizabi", Language Assessment Quarterly, Vol. 13, No. 2 (2016), 186-201. Retrieved from: https://doi.org/10.1080/ 15434303.2016.1211132.

Hasanah, Nur Hafidhotul, "Efektifitas Pelaksanaan Program Ekstrakurikuler Baca Tulis Al-Qur'an Bagi Siswa Kelas VII MTsN Sumberagung Jetis Bantul", Jurnal Pendidikan Agama Islam, Vol. X, No.1 (2013), 59-85.

Hasri, dan Nur Rahmah, "Kemampuan Baca Tulis Al - Quran

Dan Korelasinya Terhadap Kemampuan Matematika Mahasiswa Prodi Tadris Matematika IAIN Palopo", AlKhwarizmi: Jurnal Pendidikan Matematika Dan Ilmu Pengetahuan Alam, Vol. 4, No.2 (2016), 163-72. 
Herwin, dan Sumantri, "Studi Generalizabilitas Multifacet Pada Instrumen Penilaian Menulis Karangan Di Sekolah Dasar", in Prosiding Kongres Dan Konferensi Ilmiah Himpunan Evaluasi Pendidikan (HEPI) Tahun 2015, pp. 155-59

Izza, L.N, E. Susilaningsih, and Harjito, "Analisis Instrumen Performance Assessment Dengan Metode Generalizability Coefficient Pada Keterampilan Dasar Laboratorium", Chemistry in Education, Vol. 3, No.1 (2014), 30-36. Retrieved from: http://journal.unnes.ac.id/sju/index.php.

Jumaeda, St., "Ma'had Al -Jamiah Di Institut Agama Islam Negeri Ambon", Jurnal Al-Iltizam, Vol. 2, No.1 (2017), 111.

Linn, Robert L, "Measurement and evaluation in teaching", New York: Macmillan Publishing Company, (1990), 143. Mssraty, Tariq, and Qais Faryadi, "Teaching the Qur' Anic Recitation with Harakatt: A Multimedia-Based Interactive Learning Method", International Journal of Scientific \& Engineering Research, Vol. 3, No.8 (2012), 14.

Ofianto, and Suhartono, "An Assessment Model Of Historical Thinking Skills By Means Of The Rasch Model", Research and Evaluation in Education Journal, Vol. 1, No. 1 (2015), 73-83. Retrieved from: http://journal.uny.ac.id/index. php/reid.

Otaya, Lian G, "Urgensi Sikap Mahasiswa Menilai Kemampuan Diri Dalam Belajar Melalui Asesmen Diri (Self Assessment)", Tadbir Jurnal Manajemen Pendidikan Islam, Vol. 3, No.1 (2015), 58-67.

Rizki, Muhammad, "Pembinaan Kemampuan Membaca AlQur'an Mahasiswa Prodi Pendidikan Agama Islam Melalui Program Ma'had Al-Jamiah UIN Ar-Raniry", Universitas Islam Negeri Ar-Raniry, 2016.

Rohimin, Chairur, "Pelaksanaan Program Baca Tulis AlQur'an Di P3KMI IAIN Surakarta Tahun Akademik 2016/2017", Institut Agama Islam Negeri Surakarta untuk, 2017. 
Saleh, Muhammad Hafiz, Zaharah Hussin, Zawawi Ismail, Zulkiple Abd Gani, Adnan Mohamed Yusoff, and Hayati Hussin, "Developing An Effective Quran Memorisation Technique Using Fuzzy Delphi Method", Al-Qanatir: International Journal of Islamic Studies, Vol. 7, No.1 (2017). Retrieved from: http://myjms.mohe.gov.my/ index.php/alqanatir.

Samad, Musdelifa Abu, "Sistem Pembelajaran Bahasa Arab Di IAIN Sultan Amai Gorontalo" Program Pascasarjana Universitas Islam Negeri (UIN) Alauddin Makassar, 2012.

Sarikin, "Peningkatan Kemampuan Membaca Al-Quran Dengan Metode Cooperatif Learning Mencari Pasangan", Jurnal Ilmu Tarbiyah 'At-Tajdid', Vol. 1, No.1 (2012), 7187.

Shavelson, Richard J., "Generalizability Theory", New Bury Park California: Sage Publications, 2017. Retrieved from:

https://doi.org/10.1002/9781118625392.wbecp352

Suviana, Vivin Andria, "Implementasi Praktikum Baca Tulis Al-Qur'an (BTQ) Dalam Mengembangkan Kemampuan Menghafal Al-Qur'an Mahasiswa Jurusan Tadris Matematika (TMT) FTIK IAIN Tulungagung Tahun 2015", Institut Agama Islam Negeri Tulungagung, 2016.

Tamrin, "Pola Pembinaan Tahsin Alquran Di Kalangan Mahasiswa (Analisis Pola Pembinaan Pada Himpunan Qari Qariah Mahasiswa Sulawesi Tengah (HIQMAH) ", Rausyan Fikr, Vol. 12, No.2 (2016), 315-50. 